\title{
Boron Content on Microstructure and Mechanical Properties of Amorphous Boron Carbide by Chemical Vapor Deposition
}

\author{
QIAO Zhen-Jie ${ }^{1,2,3,4}$, GAO Le ${ }^{1,2}$, FENG Qian ${ }^{5}$, HU Jian-Bao ${ }^{1,2}$, DONG Shao-Ming ${ }^{1,2}$, MA Liang-Lai ${ }^{1,2,3}$
}

(1. State Key Laboratory of High Performance Ceramics and Superfine Microstructure, Shanghai Institute of Ceramics, Chinese Academy of Sciences, Shanghai 200050, China; 2. Structural Ceramics and Composites Engineering Research Center, Shanghai Institute of Ceramics, Chinese Academy of Sciences, Shanghai 200050, China; 3. University of Chinese Academy of Sciences, Beijing 100049, China; 4. School of Physical Science and Technology, Shanghai Tech University, Shanghai 201210, China; 5. Analysis and Testing Center, Donghua University, Shanghai 201620, China)

\begin{abstract}
Boron carbide coatings $\mathrm{B}_{x} \mathrm{C}_{1-x}(x=0.05,0.10,0.16,0.30,0.50)$ were prepared by low pressure chemical vapor deposition technique from $\mathrm{BCl}_{3}-\mathrm{C}_{3} \mathrm{H}_{6}-\mathrm{H}_{2}$ precursor mixtures. The effects of boron content on the microstructure and mechanical behaviors of the $\mathrm{B}_{x} \mathrm{C}_{1-x}$ were investigated. The $\mathrm{B}_{0.1} \mathrm{C}_{0.9}$ coating displayed a graphite-like structure of high crystallinity where a large fraction of boron atoms exists as atomic substituent in the carbon layers. As boron content increased, the structure tended to be amorphous, because of the formation of increasingly numbers of B-C bonds. The $\mathrm{B}_{0.1} \mathrm{C}_{0.9}$ coating showed a low hardness and elastic modulus, and its mechanical behavior was close to that of an elastic soft film. The $\mathrm{H}$ and $\mathrm{E}$ of $\mathrm{B}_{x} \mathrm{C}_{1-x}$ coatings were significantly enhanced at high boron content level, because of the formation of increasing amounts boron carbide in them.
\end{abstract}

Key words: boron carbide; microstructure; mechanical properties; low pressure chemical vapor deposition

Continuous fiber reinforced silicon carbide ceramic matrix composites (CMCs), such as $\mathrm{C} / \mathrm{SiC}, \mathrm{SiC} / \mathrm{SiC}$, are popular in the aviation and aerospace fields because of their low density, excellent mechanical property, especially at high temperature ${ }^{[1-3]}$. In CMCs, pyrolytic carbon is widely used as the interphase material for stress transferring and crack deflection purposes, due to its anisotropic structure ${ }^{[4-5]}$. Nevertheless, the carbon fiber and the carbon interphase are vulnerable to oxygen when the temperature is over $500{ }^{\circ} \mathrm{C}$, hereby limiting the high temperature application ${ }^{[6]}$.

Boron element is a self-healing phase for oxidation protection. It can build a barrier inhibiting the diffusion of oxygen by forming boron oxide glass at high temperature over $600^{\circ} \mathrm{C}^{[7]}$. The most often used boron containing material for oxidation protecting is boron carbide due to its excellent mechanical properties even at high temperature. The CMCs with the $\mathrm{Si}-\mathrm{B}-\mathrm{C}^{[8]}$ or [SiC$\left.\mathrm{B}_{4} \mathrm{C}\right]_{n}^{[7,9]}$ multi-layers coatings or matrixes exhibit excellent oxidation resistance and enhanced lifetime at high temperature oxidation environment. Moreover, boron is also known as a catalyst for the graphitization of carbon, it can enter graphite lattice by substituting carbon at- oms $^{[10-11]}$.

Chemical vapor deposition (CVD) is the most suitable method to realize homogeneous doping of carbon with boron. Way, et al ${ }^{[12]}$ prepared $\mathrm{B}_{x} \mathrm{C}_{1-x}$ materials from $\mathrm{BCl}_{3}-\mathrm{C}_{6} \mathrm{H}_{6}$ gaseous precursors with a maximum boron content of 15at\%-17at\%. Kouvetakis, et al ${ }^{[13]}$ synthesized graphite-like $\mathrm{BC}_{3}$ materials by $\mathrm{CVD}$ using $\mathrm{BCl}_{3}$ and $\mathrm{C}_{6} \mathrm{H}_{6}$ gaseous precursors at $800^{\circ} \mathrm{C}$. The $\mathrm{BC}_{3}$ materials showed a much greater resistance to oxidation than T-300 carbon fibers in the temperature range from $673 \mathrm{~K}$ to $1073 \mathrm{~K}$ reported by Fecko ${ }^{[14]}$, but the deposition rate of $0.01-$ $0.05 \mu \mathrm{m} / \mathrm{d}$ is low and no single crystal have been obtained so far, which limits its practical application. Jacques, et $a l^{[15]}$ studied the structures of $\mathrm{B}_{x} \mathrm{C}_{1-x}$ coatings, and found that such coatings exhibited various degree of anisotropy with different boron contents. Kulikovsky, et $a l^{[16]}$ made a detail study on the mechanical properties and structure of amorphous $\mathrm{B}_{4} \mathrm{C}$ films, but the films were prepared by magnetron sputtering which was not suitable for CMCs. Up to now, no report about the relationship between structure and mechanical properties of the $\mathrm{B}_{x} \mathrm{C}_{1-x}$ by CVD can be found.

In the present work, $\mathrm{B}_{x} \mathrm{C}_{1-x}$ coatings were prepared

Received date: 2017-02-14; Modified date: 2017-03-15

Foundation item: National Natural Science Foundation of China (51502323); Shanghai Natural Science Foundation (14ZR1445800); Shanghai Key Project of Basic Research (14JC1406200); Science Foundation for Youth Scholar of State Key Laboratory of High Performance Ceramics and Superfine Microstructures (SKL201601)

Biography: QIAO Zhen-Jie (1991-), male, candidate of Master degree. E-mail:qiaozhj@shanghaitech.edu.cn

Corresponding author: GAO Le, senior engineer. E-mail: gaole@mail.sic.ac.cn; DONG Shao-Ming, professor. E-mail: smdong@mial.sic.ac.cn 
from the $\mathrm{BCl}_{3}-\mathrm{C}_{3} \mathrm{H}_{6}-\mathrm{H}_{2}$ mixture, since $\mathrm{C}_{3} \mathrm{H}_{6}$ was the most used pyrolysis carbon precursor in the CVD system ${ }^{[17]}$. The structures of $\mathrm{B}_{x} \mathrm{C}_{1-x}$ coatings with different boron content were studied and the mechanical behaviors including elastic modulus and hardness were analyzed by the nano-indentation technique.

\section{Experiments}

\subsection{Films preparation}

$\mathrm{B}_{x} \mathrm{C}_{1-x}$ coatings were deposited on SiC plates in a low-pressure hot-wall chemical vapor deposition reactor at $1173 \mathrm{~K}$ and $1.0 \mathrm{kPa}$, using $\mathrm{BCl}_{3}-\mathrm{C}_{3} \mathrm{H}_{6}-\mathrm{H}_{2}$. The flow rates of the reactant gases were measured and regulated by mass flow meters. The flow of $\mathrm{Ar}$ and $\mathrm{H}_{2}$ were fixed at $100 \mathrm{sccm}$ and $50 \mathrm{sccm}$. The total flow of $\mathrm{BCl}_{3}$ and $\mathrm{C}_{3} \mathrm{H}_{6}$ was fixed at $20 \mathrm{sccm}$. The atomic ratio of boron to carbon in the reactant gases were set respectively as $1: 5$, $1: 3,1: 1,3: 1,5: 1$, so that $B_{x} C_{1-x}$ coatings with different boron contents could be prepared.

\subsection{Characterization}

Phases existing in the coatings were characterized by grazing incidence X-ray diffraction (XRD, Rigaku $\mathrm{D} / \max 2550 \mathrm{~V}$ ). The glancing incidence was fixed at $1^{\circ}$. The composition and element chemical states of the $\mathrm{B}_{x} \mathrm{C}_{1-x}$ films were analyzed by X-ray photoelectron spectroscopy (XPS, thermos scientific ESCALAB 250). The $\mathrm{X}$-ray resource of XPS was generated by a monochromated $\mathrm{Al} \mathrm{K \alpha}(1486.6 \mathrm{eV})$ radiation $(15 \mathrm{kV}, 7 \mathrm{~mA})$. The coating surfaces were cleaned by argon ions before XPS analysis. The nanostructure of the coatings was observed by transmission electron microscopy (TEM, JEM-2100F) operated with electron acceleration voltage of $200 \mathrm{kV}$ and the two-point resolution of $0.19 \mathrm{~nm}$.

The hardness and modulus of the coatings were determined using Agilent G200 Nanomechanical Tester equipped with a Berkovitch diamond tip (TB21090) at room temperature in the continuous stiffness measurement (CSM) mode. The maximum indentation depth varied with the thickness of the coatings, but all fixed at the $10 \%$ of the coatings thickness to avoid the substrate effect.

\section{Results and discussion}

\subsection{Chemical composition}

The chemical composition of $\mathrm{B}_{x} \mathrm{C}_{1-x}$ were analyzed by XPS. The element contents in the $\mathrm{B}_{x} \mathrm{C}_{1-x}$ coatings, the atom ratio $\mathrm{B} / \mathrm{C}$ and the precursor gas flow ratio $\alpha(\%)=$ $100 \cdot Q\left(\mathrm{BCl}_{3}\right) /\left[Q\left(\mathrm{C}_{3} \mathrm{H}_{6}\right)+Q\left(\mathrm{BCl}_{3}\right)\right]$ in the initial reactant gases are shown in Table 1 ( $\mathrm{Q}$ means gas-flow rate). The $\mathrm{B}_{x} \mathrm{C}_{1-x}$ coatings are denoted as coatings $\mathrm{I}$ to $\mathrm{V}$ with the increasing boron content. Oxygen element is inevitably detected, because the boron atoms in the surface of the coatings are liable to be oxidized in air. The oxygen contents of all coatings are about 3at\%, which will not be discussed here.

\subsection{Structure}

Figure 1 shows the XRD patterns of these coatings, where all diffraction peaks are related to turbostratic carbons. The coatings I shows a broad (002) peak, meaning poor crystallization of carbon. A sharp and intense (002) peak is observed in the pattern of coating II, indicating an obvious improvement of the graphitization level. As the boron contents of the coatings increase further, the intensity of the peaks exhibits a gradual decrease, showing a continuous amorphization of the structure.

The element chemical states of boron atoms are analyzed by XPS. Figure 2 shows the typical XPS spectra of boron (B1s) in the $\mathrm{B}_{x} \mathrm{C}_{1-x}$ films. The $\mathrm{B} 1$ core spectra are calibrated by surface contaminant carbon $(285.0 \mathrm{eV})$. The peaks centered at different binding energy stand for the diverse chemical states of boron ${ }^{[15-21]}$. The peaks at 188.5 and $189.5 \mathrm{eV}$ can be assigned to B-C bond in boron carbide environment and graphite structure, respectively. The other three peaks of higher binding energy can be attributed to various oxide states of boron, i.e. $\mathrm{BC}_{2} \mathrm{O}$ at $190.5 \mathrm{eV}, \mathrm{BCO}_{2}$ at $192 \mathrm{eV}$ and $\mathrm{B}_{2} \mathrm{O}_{3}$ at $193.4 \mathrm{eV}$.

For coating I, II and III, boron exists mainly as substitutional atoms in a graphite structure. Contrarily, boron existing in boron carbide environment takes the dominant position for coating IV and V. No boron atom cluster can be observed for all these coatings (Table 2).

Table 1 Boron contents of the $B_{x} C_{1-x}$ coatings

\begin{tabular}{cccccc}
\hline $\mathrm{B}_{x} \mathrm{C}_{1-x}$ & $\mathrm{I}$ & $\mathrm{II}$ & $\mathrm{III}$ & $\mathrm{IV}$ & $\mathrm{V}$ \\
\hline $\mathrm{B} / \mathrm{C}$ & $1: 5$ & $1: 3$ & $1: 1$ & $3: 1$ & $5: 1$ \\
$\alpha(\%)$ & 37.5 & 50.0 & 75.0 & 90.0 & 93.8 \\
$\mathrm{~B}(\mathrm{at} \%)$ & 4.9 & 9.6 & 16.3 & 30.5 & 49.5 \\
$x$ & 0.05 & 0.10 & 0.16 & 0.31 & 0.50 \\
\hline
\end{tabular}

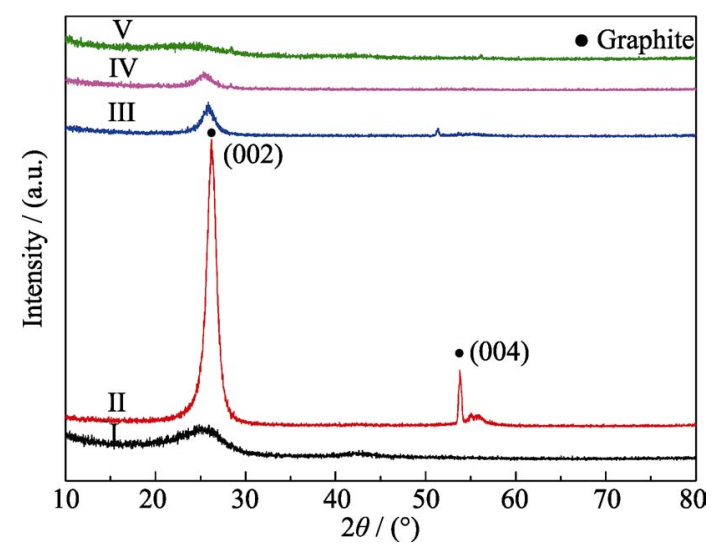

Fig. 1 XRD patterns of $B_{x} C_{1-x}$ coatings 


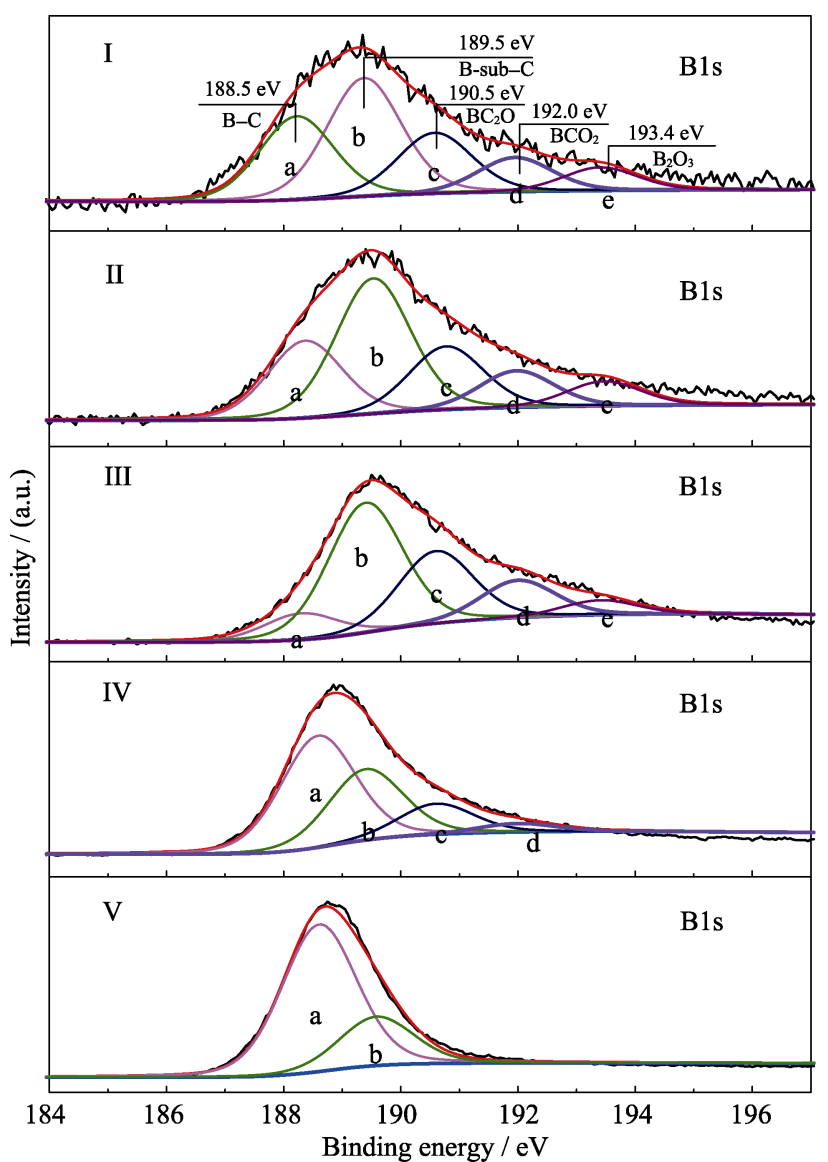

Fig. 2 B1s core level spectra and fitting curves of the $B_{x} C_{1-x}$ coatings

Table 2 Proportions of B1s components for the $B_{x} C_{1-x}$ coatings

\begin{tabular}{cccccc}
\hline $\mathrm{B}_{x} \mathrm{C}_{1-x}$ & $\mathrm{I}$ & $\mathrm{II}$ & $\mathrm{III}$ & $\mathrm{IV}$ & $\mathrm{V}$ \\
\hline a B-C in $\mathrm{B}_{4} \mathrm{C} / \%$ & 26.7 & 23.0 & 9.5 & 50.4 & 75.1 \\
b B-sub-C/\% & 37.0 & 40.2 & 46.3 & 32.0 & 24.9 \\
c BC $2 \mathrm{O} / \%$ & 19.0 & 18.7 & 25.8 & 13.8 & 0 \\
d BCO$_{2} / \%$ & 10.7 & 10.8 & 13.3 & 3.8 & 0 \\
${\text { e } \mathrm{B}_{2} \mathrm{O}_{3} / \%}^{7.3}$ & 7.3 & 5.2 & 0 & 0 \\
\hline
\end{tabular}

In order to interpret the nanostructures of the coatings further, four representative coatings (II, III, IV and V) are observed by TEM. The fringe lattice images of the coatings are shown in the Figure 3 and the SAED patterns are shown as the insets. The orientation of lattice fringes of Figure 3(a) is uniform with a layer space of $0.34 \mathrm{~nm}$, which is matched to (002) spacing of the graphite bulks, indicating the high crystallinity of the graphite. The (002) and (004) arcs are as short as the spots shown in the diffraction pattern, which also confirms the high graphitization of the coating II. Besides, the cross links with the twisting and waving styles can be observed in the Figure 3(a). In Figure 3(b), the electron diffraction pattern of coating III exhibits a crescent (002) arc, which means the orientation of the carbon layers is partly variant, but still low anisotropy. Meanwhile, the small crystallite size can
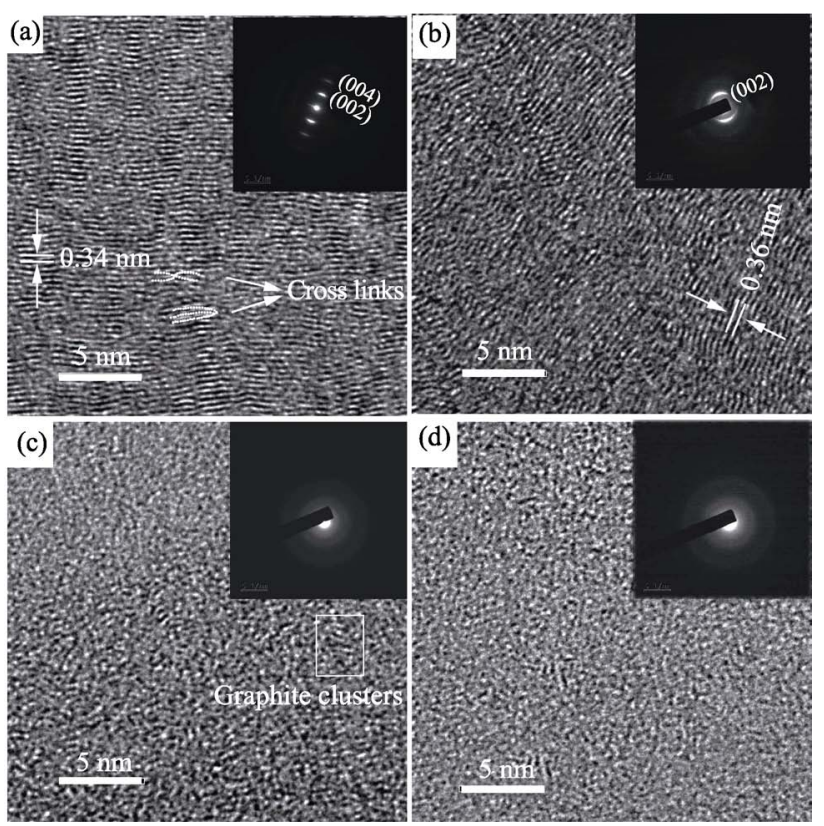

Fig. 3 Nanostructures of $\mathrm{B}_{x} \mathrm{C}_{1-x}$ coatings

(a) Coating II; (b) Coating III; (c) Coating IV; (d) Coating V

enlarge the amount of boron present at the crystallite periphery, increasing the fraction of substitutional boron in the carbon layer ${ }^{[15]}$. This is associated with the XPS results shown in Table 2 . It can also be observed from the fringe image, the layer space of $0.36 \mathrm{~nm}$ is larger than that of the coating II, and the curly carbon layers are inferred to be caused by the intercalating boron atoms between carbon layers. For the coating IV, the diffraction patterns are rings, indicating the amorphous structure. But the short graphite cluster is still found in the amorphous structure. The coating $\mathrm{V}$ shows a totally amorphous structure as the diffraction rings are more blurry compared to that of coating IV, and no any nanocrystal phase can be found in Figure 3(d). The information obtained by TEM is in accordance with the previous results obtained by XRD.

The effects of boron atoms on the structure of carbon can be summarized as follows. At low content, boron atoms can promote the formation of rings and hinder the production of turbostratic carbons by substituting carbon atoms with its strong adsorption of electron. As boron contents increases, more boron will take the interstitial sites of the carbon layers, resulting in the increase of $d_{002}$-spacing, formation of curly carbon layers, and the non-uniform orientation of carbon layers. The excessive boron will damage the organization of carbon layers further, forming amorphous boron carbide.

\subsection{Mechanical tests}

Figure 4 shows the typical load-displacement curves of coating II-V. The loading and unloading curves are al most reversible in Figure 4(a), indicating that the deformation of coating II is reversible. The deformation 

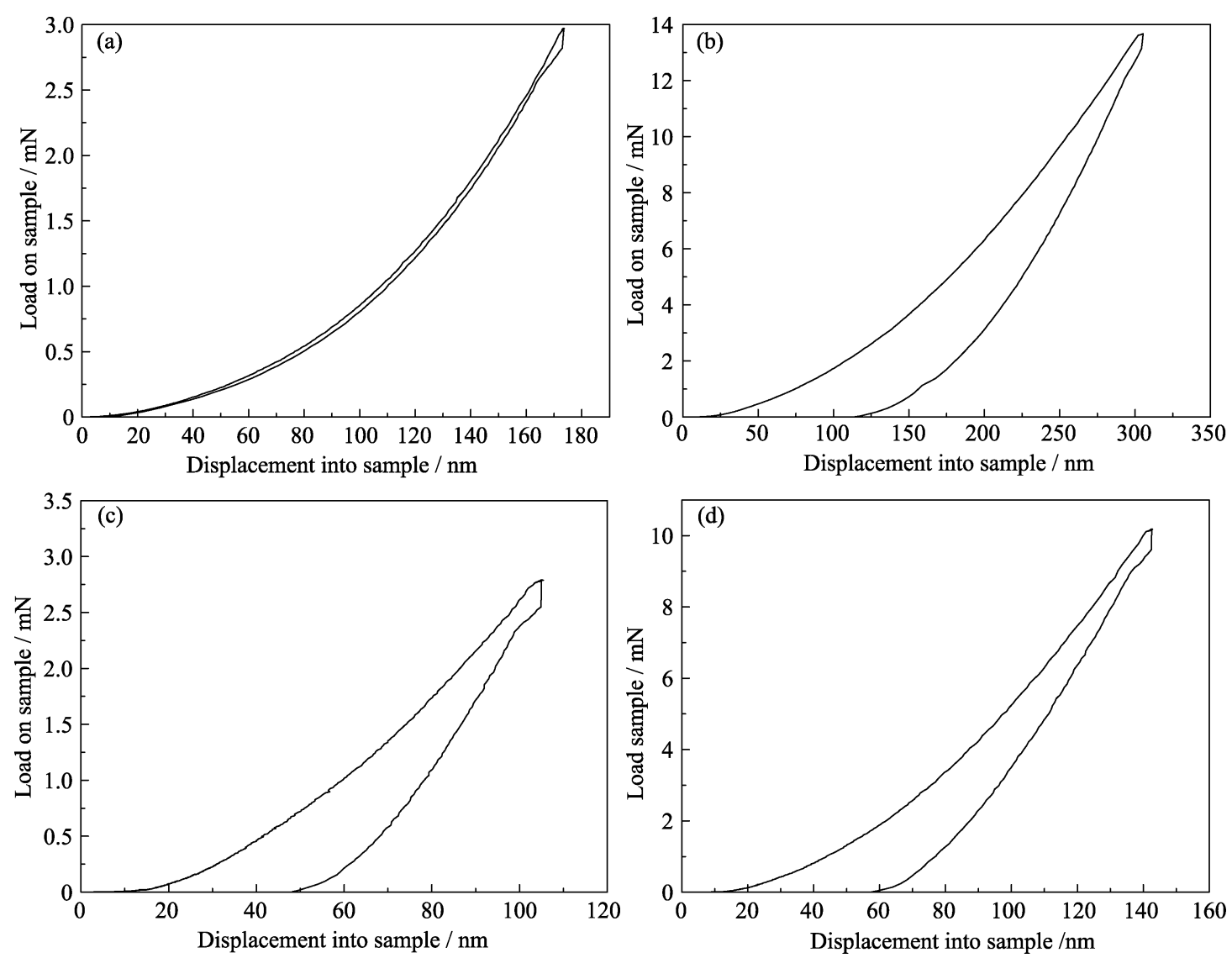

Fig. 4 Load-displacement curves of the coatings

(a) Coating II; (b) Coating III; (c) Coating IV; (d) Coating V

behavior can be explained by the mode of kink bands ${ }^{[22]}$. The generated incipient kink bands under load facilitates the movement of dislocation walls, which, in turn, coalesce into kink boundaries with increasing stress. The incipient kink bands are fully reversible. As the orientation of the graphite layer is parallel to the basal planes, the kink bands can move reversibly with relatively large distances. The cross-linked crystallites shown in Figure 3(a) also contribute to the elastic behaviors ${ }^{[23]}$. The shapes of loaddisplacement curves of coating III-V conform to the type of brittle materials. Residual impression can be found after unloading, which is the result of plastic deformation.

The average modulus and hardness are calculated from ten values for each coating, which are listed in Table 3.

Table 3 Elastic modulus and hardness for the $B_{x} C_{1-x}$ coatings

\begin{tabular}{ccccc}
\hline $\mathrm{B}_{x} \mathrm{C}_{1-x}$ & II & III & IV & V \\
\hline$E / G P a$ & $46.0 \pm 4.6$ & $100.0 \pm 13.3$ & $161.2 \pm 34.5$ & $415.0 \pm 41.7$ \\
$H / G P a$ & $5.66 \pm 0.84$ & $10.44 \pm 2.49$ & $15.29 \pm 5.02$ & $39.77 \pm 4.9 .0$ \\
\hline
\end{tabular}

The modulus and hardness of the coatings are significantly enhanced with the increase of boron doping level, due to the formation of increasing amount of boron carbide in them as indicated by the XPS analysis. The elastic modulus and hardness of crystalline $\mathrm{B}_{4} \mathrm{C}$ are reportedly $440 \mathrm{GPa}$ and $25-40 \mathrm{GPa}^{[24-26]}$, respectively. Here, coating $\mathrm{V}$ shows comparably high elastic modulus (415 \pm 41.7) GPa and hardness (39.77 \pm 4.9 ) GPa as crystalline $\mathrm{B}_{4} \mathrm{C}$. This coating exhibits a totally amorphous structure without obvious defects, such as crystal boundary and dislocation, which may also contribute to the high elastic modulus and hardness.

\section{Conclusions}

Boron carbide coatings are obtained in the $\mathrm{BCl}_{3}-\mathrm{C}_{3} \mathrm{H}_{6}$ $\mathrm{H}_{2}$ LPCVD system with the boron contents ranging from 5.0 at\% to 50.0 at $\%$. The coating with 10.0 at\% boron exhibits high degree of graphitization with a uniform orientation of graphite layers, where a large fraction of the boron atoms exist as substitutional atoms in graphite lattice. The mechanical behavior of the coating is similar to that of an elastic solid with a reversible load-unload curve. As the boron content increases, the structures become gradually amorphous as a result of increasing interstitial boron atoms, and the mechanical properties are enhanced due to the formation of boron carbide. The coating with high graphitization level and reversible elastic deformation should be advantageous for use as the interphase material in CMCs. While the coatings of high boron content, which possess excellent mechanical properties and potential oxidation resistance, will also be 
useful in the design of CMCs.

\section{References:}

[1] NASLAIN R. Design, preparation and properties of non oxide CMCs for application in engines and nuclear reactors: an overview. Composites Science and Technology, 2004, 64(2): 155-170.

[2] WANG D K, DONG S M, ZHOU H J, et al. Effect of pyrolytic carbon interface on the properties of $3 \mathrm{D} \mathrm{C} / \mathrm{ZrC}-\mathrm{SiC}$ composites fabricated by reactive melt infiltration. Ceramics International, 2016, 42(8): 10272-10278.

[3] ZHOU H J, DONG S M, HE P, et al. Tribological behaviors and anti-wear mechanisms of carbon/carbon-silicon carbide composites. Journal of Inorganic Materials, 2013, 28(10): 1057-1061.

[4] NASLAIN R. The design of the fiber-matrix interfacial zone in ceramic matrix composites. Composites Part A, 1998, 29(9): 1145-1155.

[5] CARRERE N, MARTIN E, LAMON J. The influence of the interphase and associated interfaces on the deflection of matrix cracks in ceramic matrix composites. Composites Part A, 2000, 31(11): 1179-1190.

[6] LAMOUROUX F, BERTRAND S, PAILLER R, et al. Oxidation-resistant carbon-fiber-reinforced ceramic-matrix composites. Composites Science and Technology, 1999, 59(7): 1073-1085.

[7] NASLAIN R, GUETTE A, REBILLAT F, et al. Boron-bearing species in ceramic matrix composites for long-term aerospace applications. Journal of Solid State Chemistry, 2004, 177(2): 449- 450.

[8] PALLIER C, CHOLLON G, WEISBECKER P, et al. Structural changes of CVD Si-B-C coatings under thermal annealing. Surface \&Coating Technology, 2013, 215: 178-185.

[9] LIU Y S, WAN J, ZUO X, et al. Oxidation behavior of 2D C/SiC composites coated with multi-layer $\mathrm{SiC} / \mathrm{Si}-\mathrm{B}-\mathrm{C} / \mathrm{SiC}$ coatings under wet oxygen atmosphere. Applied Surface Science, 2015, 353: 214-223.

[10] WU B, DONG S M, WANG Z, et al. Properties of $\mathrm{C}_{\mathrm{f}} / \mathrm{SiC}$ composites modified by a boron-containing phase. Ceramics International, 2013, 39(4): 4729-4734.

[11] OYA A, YAMASHITA R, OTANI S. Catalytic graphitization of carbons by borons. Fuel, 1979, 58(7): 495-500.

[12] WAY B, DAHN J. The effect of boron substitution in carbon on the intercalation of lithium in $\mathrm{Li}_{x}\left(\mathrm{~B}_{z} \mathrm{C}_{1-z}\right)_{6}$. Journal of the Electrochemical Society, 1994, 141(4): 907-912.

[13] KOUVETAKIS J, KANER J, SATTLER M, et al. A novel graphite-like material of composition $\mathrm{BC}_{3}$ and nitrogen-carbon graphites. Journal of the Chemical Society-Chemical Communications, 1986,
24: $1758-1759$.

[14] FECKO D, JONES L, THROWER P. The formation and oxidation of $\mathrm{BC}_{3}$, a new graphtielike material. Carbon, 1993, 31(4): 637-644.

[15] JACQUES S, GUETTE A, BOURRAT X, et al. LPCVD and characterization of boron-containing pyrocarbon materials. Carbon, 1996, 34(9): 1135-1143.

[16] KULIKOVSKY V, VORLICEK V, BOHAC P, et al. Mechanical properties and structure of amorphous and crystalline $\mathrm{B}_{4} \mathrm{C}$ films. Diamond \& Related Materials, 2009, 18: 27-33.

[17] LI H, LI A, BAI R, et al. Numerical simulation of chemical vapor infiltration of propylene into $\mathrm{C} / \mathrm{C}$ composites with reduced multi-step kinetic models. Carbon, 2005, 43(14): 2937-2950.

[18] ZIEGLER I, FOURNET R, MARQUAIRE P. Pyrolysis of propane for CVI of pyrocarbon Part I. Experimental and modeling study of the formation of toluene and aliphatic species. Journal of Analytical Applied Pyrolysis, 2005, 73(2): 212-230.

[19] WU S J, CHENG L F, ZHANG L T, et al. Comparison of oxidation behaviors of 3D C/PyC/SiC and $\mathrm{SiC} / \mathrm{PyC} / \mathrm{SiC}$ composites in an $\mathrm{O}_{2}$ - $\mathrm{Ar}$ atmosphere. Materials Science and Engineering B-Solid State Materials for Advanced Technology, 2006, 130(1/2/3): 215-219.

[20] WU S J, CHENG L F, ZHANG L T, et al. Tension-tension fatigue damage characteristics of a 3D SiC/SiC composite in $\mathrm{H}_{2} \mathrm{O}-\mathrm{O}_{2}-\mathrm{Ar}$ environment at 1300 degree C. Materials Science and Engineering A-Structural Materials Properties Microstructure and Processing, 2006, 435: 412-417.

[21] JACOBSOHN J, SCHULZE R, COSTA M, et al. X-ray photoelectron spectroscopy investigation of boron carbide films deposited by sputtering. Surface Science, 2004, 572(2/3): 418-424.

[22] BARSOUM M, MURUGAIAH A, KALIDINDI S, et al. Kink bands, nonlinear elasticity and nanoindentations in graphite. Carbon, 2004, 42(8/9): 1435-1445.

[23] ZALALUTDINOV M, ROBINSON J, JUNKERMEIER C, et al. Engineering graphene mechanical systems. Nano Letters, 2012, 12(8): 4212-4218.

[24] DOMNICH V, REYNAUD S, HABER R, et al. Boron carbide: structure, properties, and stability under stress. Journal of the American Ceramic Society, 2011, 94(11): 3605-3628.

[25] MAURI F, VAST N, PICKARD C. Atomic structure of icosahedral $\mathrm{B}_{4} \mathrm{C}$ boron carbide from a first principles analysis of NMR spectra. Physical Review Letter, 2001, 87(8): 085506-1-4.

[26] KWEI G, MOROSIN B. Structures of the boron-rich boron carbides from neutron powder diffraction: implications for the nature of the inter-icosahedral chains. Journal of Physical Chemical, 1996, 100(19): 8031-8039.

\section{嗍含量对碳硼化合物结构、力学影响行为研究}

$$
\text { 乔振杰 }{ }^{1,2,3,4} \text {, 高 乐 }{ }^{1,2} \text {, 冯 } \text { 倩 }^{5} \text {, 胡建宝 }{ }^{1,2} \text {, 董绍明 }{ }^{1,2} \text {, 马良来 }{ }^{1,2,3}
$$

(1. 中国科学院 上海硅酸盐研究所, 高性能陶瓷和超微结构国家重点实验室, 上海 200050; 2 . 中国科学院上海 硅酸盐研究所, 结构陶瓷与复合材料工程研究中心, 上海 200050; 3. 中国科学院大学, 北京 100049; 4. 上海科技 大学 物质科学与技术学院，上海 201210; 5. 东华大学 分析测试中心，上海 201620)

摘 要: 利用低压化学气相沉积技术, 以 $\mathrm{BCl}_{3}-\mathrm{C}_{3} \mathrm{H}_{6}-\mathrm{H}_{2}$ 为反应气体制备了不同掺硼量的热解碳薄膜 $\mathrm{B}_{x} \mathrm{C}_{1-x}(x=0.05$, $0.10,0.16,0.30,0.50)$, 并研究了硼含量对 $\mathrm{B}_{x} \mathrm{C}_{1-x}$ 微观结构及力学性能的影响。 $\mathrm{B}_{0.1} \mathrm{C}_{0.9}$ 展现了高度结晶的类石墨结构, 其中大部分 $\mathrm{B}$ 取代石墨层中的 $\mathrm{C}$ 。随着 $\mathrm{B}$ 含量上升, $\mathrm{B}$ 主要形成 $\mathrm{B}-\mathrm{C}$ 键, $\mathrm{B}_{x} \mathrm{C}_{1-x}$ 结构向无定型转变。纳米压痕测试结 果显示, $\mathrm{B}_{0.1} \mathrm{C}_{0.9}$ 的弹性模量和硬度较低, 载荷位移曲线显示其力学变形接近弹性变形, 随着 $\mathrm{B}$ 含量增加, 碳化硼生成 量增加, 其弹性模量和硬度显著提升, 载荷位移曲线表现出典型的脆性材料力学行为。

关 键 词: 碳硼化合物; 微观结构; 力学性质; 低压化学气相沉积

中图分类号: TQ174 文献标识码: A 